\title{
TIPOLOGIJA STANOVANJSKIH OBMOČIJ OB UPORABI METODE RAZVRŠČANJA V SKUPINE NA PRIMERU CELJA, KOPRA IN NOVEGA MESTA
}

\author{
Dejan Rebernik*
}

\section{Izvleček}

UDK $911 \cdot 375 \cdot 64: 728$ (497.12)

$S$ pomočjo metode razvrščanja v skupine so na osnovi nekaterih socio-ekonomskih in demografskih značilnosti prebivalstva ter morfoloških elementov mestne strukture določena homogena stanovanjska območja na primeru treh slovenskih mest.

Ključne besede: morfološka sestava mesta, socialna sestava mesta, multivariantna analiza, Celje, Koper, Novo mesto

\section{TYPOLOGY OF RESIDENTIAL DISTRICTS THROUGH THE APPLICATION OF CLUSTER ANALYSIS IN THE CASES OF CELJE, KOPER, AND NOVO MESTO}

Abstract

UDC $911 \cdot 375 \cdot 64: 728$ (497.12)

By means of cluster analysis, homogeneous residential areas were defined in the cases of three Slovenian towns, on the basis of certain socio-economic and demographic characteristics of the population and morphological elements of the urban structure.

Key words: Morphological structure of town, Social structure of town, Multivariant analysis, Celje, Koper, Novo mesto

\section{PROBLEM IN CILJI NALOGE}

Na podlagi podatkov o socialni strukturi prebivalstva in morfološki zgradbi urbanega prostora želimo razdeliti mesto na homogena območja. Gre torej za problem kompleksne tipizacije mestnih območij. Iz teorije urbane geografije in urbane sociologije je poznano, da je mesto notranje strukturirano in razdeljeno na bolj ali manj homogena socialnogeografska in morfološka območja. Socialnogeografska in morfološka členitev mesta sta sicer dva ločena pojava, ki pa sta $v$ mnogočem tesno povezana. V mnogih empiričnih analizah se je namreč pokazalo, da v določenem morfološkem tipu mesta (npr. staro mestno središče, predmestna naselja enodružinskih hiš, novejše blokovske soseske, obmestna polruralna območja itd.) živi prebivalstvo s podobno

\footnotetext{
${ }^{*}$ Dipl. geog., asistent, Oddelek za geografijo, Filozofska fakulteta Univerze v Ljubljani, Aškerčeva 2, 61000 Ljubljana, Slovenija
} 
socialno (premoženjsko, poklicno, izobrazbeno, starostno, narodnostno itd.) strukturo. Mesta v družbah $\mathrm{z}$ različno družbeno-ekonomsko ureditvijo, razvojno stopnjo in tradicijo poselitve so seveda zelo različno notranje strukturirana. Ponekod je prostorska ločitev (segregacija) različnih socialnih skupin prebivalstva zelo izrazita (npr. Angloamerika, Tretji svet ...), drugje pa v mnogo manjši meri. Tudi morfološka zgradba mest se zelo razlikuje po posameznih delih sveta.

Cilj naloge je tipizacija mestnih območij na primeru treh srednje velikih slovenskih mest: Celja, Kopra in Novega mesta. V omenjenih mestih želimo poiskati območja, ki so si kar najbolj podobna po svoji socialni in morfološki strukturi. Pri tem nas zanima tudi prostorska razporeditev tako določenih mestnih območij. Iz analize smo namenoma izključili tiste dele mesta, kjer stanovanjska funkcija ni prisotna. Ta območja smo poimenovali nestanovanjska območja. Gre predvsem za industrijske in skladiščne cone, prometne terminale, rekreacijska območja in večje komplekse javnih zgradb.

\section{OPIS IZBRANE METODE IN PODATKOV}

Razvrščanje objektov v skupine, tako da so objekti znotraj skupin kar se da podobni med seboj, objekti različnih skupin pa kar se da različni, je zelo star in razumljiv problem. Ta problem je bil do nedavnega reševan ločeno v posameznih znanstvenih disciplinah, ne da bi se tako dobljeni rezultati povezovali in dopolnjevali. V šestdesetih letih je zaznati prve poskuse združitve različnih pristopov reševanja problema razvrščanja $v$ skupine. Od tedaj se področje razvrščanja v skupine razvija kot samostojna disciplina znotraj multivariantne analize (Ferligoj, 1989).

Nalogo razvrščanja v skupine lahko zastavimo takole: dane objekte je potrebno razvrstiti v nekaj skupin med seboj (znotraj skupine) podobnih objektov. Množico skupin imenujemo razvrstitev. Opisom posameznih objektov, ki jih želimo razvrstiti v skupine pravimo enote. Enote so določene s spremenljivkami, tako da ima vsaka enota vrednost za določeno spremenljivko. Torej $i$-ta enota $X i$ je nabor vrednosti izmerjenih spremenljivk,

$$
X i=(X i 1, X i 2, X i 3 \ldots \ldots \text { Xim })
$$

pri čemer je $m$ število spremenljivk. Enote predstavljajo izhodišče za nadaljno razvrščanje in zato izbor spremenljivk odločilno vpliva na smiselnost dobljenih razvrstitev glede na zastavljeni problem. Iz značaja problema razvrščanja v skupine je potrebno čim bolj natančno opredeliti, kakšne razvrstitve so smiselne. To storimo z določitvijo množice dopustnih razvrstitev in kriterijev razvrščanja.

Razvrstitev enot, ki so določene z vrednostjo ene (ali več) številskih spremenljivk, je 
mogoče razbrati iz grafičnih predstavitev enot s točkami $v$ eno ali več-razsežnem prostoru, kjer je vsaka razsežnost določena $\mathrm{z}$ eno spremenljivko. Skupine lahko $\mathrm{v}$ takem prikazu razberemo kot relativno gosto posejane točke, ki so obkrožene s praznim prostorom ali $\mathrm{z}$ relativno redko posejanimi točkami. Tako določenim skupinam pravimi naravne skupine. Naravne skupine morajo imeti dve lastnosti: interno kohezivnost (homogenost) in eksterno izolacijo (ločenost). Za razvrščanje enot $\mathrm{z}$ več spremenljivkami je grafična metoda neuporabna, ker je težko grafično predstaviti več kot tri razsežni prostor. $V$ takih primerih je za razkrivanje strukture enot potrebno uporabiti metode, ki so ustrezne multivariantnemu načinu obravnave enot.

Prvo delo, ki je urejeno povzelo različne pristope problema razvrščanja v skupine, je izšlo leta 1963 (Sokal in Sneath: Principles of numerical taxonomy, Freeman, San Francisco). Od takrat se to področje hitro razvija, kar potrjuje tudi število člankov različnih avtorjev (Ball, Hall, Fleiss, Zubin, Jardine, Anderberg, Bijen, Hartigan in drugi). Pri nas se z razvrščanjem v skupine največ ukvarjata A. Ferligoj in V. Bagatelj.

Najpogostejši razlogi za razvrščanje enot v skupine so:

- pregledovanje podatkov: $\mathrm{z}$ metodami razvrščanja $\mathrm{v}$ skupine je mogoče učinkovito pregledati podatke (poiskati tujke, proučiti strukturo podatkov ...). V tej fazi gre za postavljanje začetnih delovnih domnev o pojavih, ki jih obravnavamo;

- zgoščanje podatkov: namesto vseh enot analiziramo skupine enot ali predstavnike skupin, ki so bile dobljene $\mathrm{z}$ ustreznimi metodami razvrščanja $\mathrm{v}$ skupine (kadar imamo velike količine podatkov);

- dolocitev tipologije: najpogostejši razlog za razvrščanje v skupine pa je empirična določitev tipologije pojavov.

Pri razvrščanju v skupine gre za določanje skupin podobnih objektov. Analitična določitev iskane razvrstitve je povezana $\mathrm{z}$ vrsto problemov. Iskane razvrstitve namreč ni mogoče poiskati z eno metodo ali pristopom z natančno določenimi pravili. Večkrat se je potrebno tudi intuitivno odločati, kaj izbrati iz množice možnih izborov v določenem koraku reševanja zastavljenega problema. Osnovni koraki pri reševanju problemov razvrščanja v skupine so:

- izbira objektov,

- določitev množice spremenljivk, ki določajo enote,

- računanje podobnosti med enotami,

- uporaba ustrezne metode razvrščanja v skupine,

- ocena dobljene rešitve.

V naslednjem koraku se moramo odločiti, katera od metod razvrščanja je najprimernejša za reševanje postavljenega problema. Večino metod lahko uvrstimo v tri osnovne skupine: hierarhične, nehierarhične in geometrijske. 
Hierarhične metode so najbolj priljubljena metoda razvrščanja v skupine. Deliti jih je mogoče na metode združevanja, kjer v vsakem koraku postopka združimo dve ali več skupin v novo skupino in metode cepitve, kjer v vsakem koraku izbrano skupino razcepimo na dve ali več skupin. Pri hierarhičnih metodah ni potrebno vnaprej opredeliti števila skupin. Rezultat postopnega združevanja je mogoče nazorno predstaviti z drevesom združevanja (dendrogram).

Nehierarhične metode se od hierarhičnih ločijo predvsem po tem, da je potrebno vnaprej podati število skupin iskane razvrstitve. Enote razvrščajo tako, da z izbranim optimizacijskim kriterijem izboljšujejo vnaprej podano začetno razvrstitev. Nehierarhične metode so iteracijske: začnejo $\mathrm{z}$ začetno razvrstitvijo s podanim številom skupin in na različne načine prestavljajo enote iz ene skupine $\mathrm{v}$ druge $\mathrm{z}$ namenom, da s temi prestavitvami dosežejo zmanjšanje (ali povečanje) vrednosti izbrane kriterijske funkcije. Ta proces se nadaljuje, dokler nobena prestavitev enote ne izboljša vrednosti kriterijske funkcije. Te metode v splošnem dajo le lokalno optimalne razvrstitve, zato je priporočljivo, da razvrščanje večkrat ponovimo $\mathrm{z}$ različnimi začetnimi razvrstitvami. Najbolj znani nehierarhični metodi sta metoda prestavljanj in metoda voditeljev.

Geometrijske metode omogočajo preslikavo podatkov iz originalnega večrazsežnostnega prostora $\mathrm{v}$ manj razsežni, pogosto kar v dvorazsežni prostor, v katerem lahko grafično ali kako drugače raziščemo strukturo podatkov. Najbolj znani geometrijski metodi sta metoda glavnih komponent in večrazsežnostno lestvičenje.

Pri ocenjevanju dobljenih rešitev ne smemo pozabiti, da vsaka metoda pri iskanju strukture $v$ podatkih vsiljuje strukturo, ki je vgrajena $v$ metodi. Nekatere metode npr. znajo razkriti le krogle, nekatere le dolge "klobase" itd. Zato je priporočljivo obravnavane enote razvrščati $\mathrm{z}$ več različnimi metodami in primerjati dobljene rešitve. Stabilne so tiste razvrstitve, ki se ne spremenijo bistveno $\mathrm{z}$ dodajanjem novih enot $\mathrm{v}$ množico enot ali $\mathrm{z}$ dodajanjem novih spremenljik med izbrane merjene spremenljivke. Objektivnost razvstitve bi lahko opredelili s ponovljivostjo rezultata: neodvisni raziskovalci naj bi prišli $\mathrm{z}$ analizo enake množice podatkov z enakim potekom razvrščanja v skupine do enakega (ali vsaj podobnega) rezultata.

Problem razvrščanja v skupine lahko zastavimo kot optimizacijski problem:

Določi razvrstitev $C^{*}$ tako, da bo

$$
\begin{gathered}
\mathrm{P}\left(C^{*}\right)=\min _{C \in \phi} \mathrm{P}(C) \\
C
\end{gathered}
$$

Kar pomeni: če imamo množico razvrstitev $\phi$ in izračunamo za vsako razvrstitev $C \in \phi$ vrednost kriterijske funkcije, je najboljša (najprimernejša) razvrstitev $\left(C^{*}\right)$ tista, ki ima najmanjšo vrednost kriterijske funkcije. 
S kriterijsko funkcijo torej opišemo, kakšna naj bo želena razvrstitev enot, ki so opisane $\mathrm{z}$ izbranimi spremenljivkami. Pri tem nas največkrat zanima interna kohezivnost (homogenost) skupin in večina kriterijskih funkcij meri prav to.

Hierarhično združevanje $v$ skupine temelji na zaporednem združevanju dveh (ali več) skupin v novo skupino. $V$ naši analizi smo uporabili združevanje dveh skupin (Hierachical cluster v programu SPSS 6.0 za Windows). Potek združevanja si lahko grafično ponazorimo $\mathrm{z}$ drevesom združevanja - dendrogramom. List tega drevesa so enote, točke združitve pa sestavljene skupine. Višina točke, ki jo imenujemo nivo združevanja, je sorazmerna meri različnosti med skupinama. Pregled nivojev združevanja nam omogoča analitično določitev primernega števila skupin. To je še posebej dobrodošlo takrat, ko ne vemo koliko izrazitih skupin se skriva $v$ strukturi podatkov. Zato smo se tudi pri izdelavi te naloge odločili za to metodo razvrščanja v skupine. Število skupin je določeno s številom vej drevesa združevanja, ki jih dobimo $\mathrm{z}$ rezanjem drevesa pri največjem skoku dveh sosednjih nivojev združevanja.

Postopek združevanja je mogoče opisati s kriterijsko funkcijo. Iz te izhaja "požrešna" hevristika, kar pomeni naslednje: postopek začnemo $\mathrm{z}$ združevanjem enot, ki nato $\mathrm{v}$ vsakem koraku združi najbližji si skupini. V naslednjih korakih se lahko izkaže, da bi bilo bolje, ko bi v prejšnjih korakih združevali drugače. To pomeni, da so razvrstitve, dobljene $\mathrm{z}$ drevesom rezanja drevesa na višjih nivojih manj zanesljive. Iz tega razloga smo poskušali $v$ tej nalogi razvrstitev dobljeno s hierarhičnim združevanjem $v$ skupine “popraviti” še z metodo voditeljev.

Metoda voditeljev sodi med metode lokalne optimizacije. Je iteracijska metoda, kjer se je potrebno odločiti $v$ koliko skupin razvrščamo enote. Postopek se začne $\mathrm{z}$ vnaprej podano množico predstavnikov posameznih skupin - voditeljev. Metoda priredi enote najbližjim voditeljem, poišče centroide (težišča) tako dobljenih skupin - nove voditelje, zopet priredi enote najbližjim voditeljem. Postopek se konča, ko se nova množica voditeljev ne razlikuje od množice voditeljev, dobljene korak pred njo. Ker je množica enot končna, je končna tudi množica vseh razvrstitev. Čim boljšo razvrstitev poskušamo dobiti tako, da postopek ponovimo večkrat $\mathrm{z}$ različnimi začetnimi množicami voditeljev. Začetno množico voditeljev lahko določimo na različne načine; najpreprosteje je, če so določeni slučajno. Bolje je, če voditelje maksimalno razpršimo med proučevanimi enotami. Najbolje pa je, da voditelje določimo na osnovi predhodno opravljene analize podatkov in domnev o strukturi proučevanih podatkov. Kot je bilo že omenjeno, smo $v$ tej nalogi kot množico začetnih voditeljev vzeli aritmetične sredine standardiziranih spremenljivk skupin, dobljenih po predhodno opravljeni metodi hierarhičnega združevanja v skupine.

Za rešitev zastavljenega problema bomo uporabili metodo hierarhičnega združevanja $v$ skupine in metodo voditeljev. Podatki o socialni in morfološki strukturi omenjenih 
mest (rezultati popisa prebivalstva, stanovanj in gospodinjstev 1991) so agregirani na nivo popisnega okoliša. Naše enote so torej popisni okoliši. Kot je že bilo omenjeno v uvodnem delu, smo iz analize izključili nestanovanjska območja. Med nestanovanjska območja smo šteli tiste popisne okoliše, ki imajo manj kot 30 prebivalcev. $\mathrm{Na}$ ta način smo izločili nekatere industrijske cone, mestne zelene površine in večje komplekse javnih zgradb. "Mešane" popisne okoliše, kjer so se locirala tako stanovanja kot "nestanovanjske" dejavnosti, smo $v$ analizo seveda vključili. V Celju je bilo po tem principu izločenih 16 popisnih okolišev, v Kopru 8 in v Novem mestu 8 . Na kartah so ti popisni okoliši prazni. Glede na število enot (201 za Celje, 108 za Koper 121 in 97 za Novo mesto) je metoda hierarhičnega združevanja v skupine primerna. Za to metodo smo se odločili tudi zato, ker nam ni poznano število skupin, to se pravi število homogenih socialno-morfoloških območij v omenjenih mestih.

Ko smo $z$ metodo hierarhičnega združevanja $v$ skupine enote razdelili v bolj ali manj homogene skupine, smo dobljeno razvrstitev vzeli kot izhodišče nadaljnega razvrščanja $v$ skupine $z$ metodo voditeljev. Sedaj nam je bila namreč poznana struktura podatkov, to se pravi število in značilnosti skupin v katere so ločeni podatki.

Izbrali smo naslednje spremenljivke:

- delež prebivalcev do 18 leta starosti

- delež prebivalcev nad 65 letom starosti

- delež prebivalcev brez šole, z nedokončano ali končano osnovno šolo

- delež prebivalcev s končano višjo ali visoko šolo

- delež neslovenskega prebivalstva

- delež industrijskih delavcev

- delež vodilnih delavcev

- delež zaposlenih v sekundarnem sektorju

- delež zaposlenih v terciarnem sektorju

- delež zaposlenih v kvartarnem sektorju

- bruto odmerjena dohodnina na prebivalca

- delež nezaposlenih

- delež samskih gospodinjstev

- stanovanjska površina na osebo

- delež stanovanj v večstanovanjskih hišah

- delež stanovanj, zgrajenih do leta 1918

- delež stanovanj, zgrajenih med leti 1919 in 1945

- delež stanovanj, zgrajenih med leti 1946 in 1970

- delež stanovanj, zgrajenih po letu 1971

Spremenljivke smo pred začetkom razvrščanja v skupine standardizirali. Uporabili smo "običajni" način standardizacije, to se pravi, da smo od vrednosti spremenljivke 
za posamezno enoto odšteli njeno aritmetično sredino in jo delili s standardnim odklonom te spremenljivke.

Podobnost med popisnimi okoliši smo merili z evklidsko razdaljo. Izdelali smo dendrograme $\mathrm{z}$ wardovo, minimalno in maksimalno metodo. Pri minimalni in maksimalni metodi je prišlo do učinka veriženja ( $\mathrm{v}$ posameznih korakih združevanja se skupinam pridružijo le posamezne enote), tako da smo dobili večje število skupin s po eno samo enoto. Očitno je torej, da posamezne skupine niso posebno izrazito ločene med seboj, tako da se je za najbolj uporabno izkazala wardova metoda.

Drevesa združevanja smo v naslednjem koraku rezali pri največjem skoku dveh sosednjih nivojev združevanja in na ta način poskušali dobiti čimbolj izrazite skupine.

Pri drevesu združevanja za Celje najprej izstopata dve skupini, ki pa nista posebno izraziti (nivoja združevanja sta zelo blizu skupaj). Zgornja skupina se razdeli na dve skupini, tako da dobimo tri izrazito ločeni skupini. Zgornji dve skupini lahko nadalje razdelimo vsako na dve skupini, tako da imamo skupaj pet skupin. Možni sta torej dve delitvi: na 3 oziroma na 5 skupin, odvisno od tega, kje režemo drevo združevanja. Za obe delitvi je značilno, da posebno izrazito izstopa spodnja skupina na drevesu združevanja (mera različnosti med to skupino in ostalimi je največja). Pri delitvi na 5 skupin pa lahko ločimo 3 "podskupine".

Tudi pri drevesu združevanja za Koper lahko ločimo dve neizraziti skupini, če drevo režemo niže pa tri dobro ločene skupine. Srednjo skupino na drevesu združevanja lahko nadalje razdelimo še na dve skupini, tako da imamo na koncu štiri skupine. Najbolj izrazito izstopa spodnja skupina, nato zgornja, nekoliko bolj podobni pa sta si srednji dve skupini.

Pri drevesu združevanja za Novo mesto lahko ločimo dve izrazito ločeni skupini. Spodnja skupina se nadalje loči na dve ne posebno dobro ločeni skupini. Kljub temu smo se odločili za delitev na tri skupine, od katerih pa sta si dve precej podobni.

$Z$ rezanjem dreves združevanja smo tako enote razdelili v skupine. Izkazalo se je, da je število izrazitih skupin po posameznih mestih različno: v Celju 3 ali 5, v Kopru 3 ali 4 in v Novem mestu 2 ali 3.

Nato smo za vsako skupino izračunali še tipične lastnosti posameznih skupin, kar prikazujejo tabele 1,2 in 3.

$\mathrm{V}$ naslednjem delu naloge smo enote razvrstili še $\mathrm{z}$ metodo voditeljev (k-means $\mathrm{v}$ programu SPSS 6.0 za Windows). Kot začetno razvrstitev smo vzeli razvrstitev, ki smo jo dobili $z$ metodo hierarhičnega združevanja $v$ skupine. Tako smo za vsako 
skupino, ki smo jo dobili s hierarhičnim združevanjem v skupine, izračunali aritmetične sredine standardiziranih spremenljivk in jih določili za začetne voditelje.

V primeru Celja so se voditelji ustalili po 6-ih ponovitvah (tabela 4). Tako dobljena razvrstev se ne razlikuje bistveno od začetne razvrstitve, kar nam pokaže primerjava začetnih in končnih voditeljev. Na splošno lahko rečemo, da so se voditelji posameznih skupin zbližali, skupine pa so ohranile osnovne značilnosti. Nekaj enot, to se pravi popisnih okolišev, pa je bilo kljub vsemu zamenjano med skupinami (precej enot se je iz prve "preselilo" v drugo skupino).

Iz tabele 5 je razvidno, da so se v primeru Kopra voditelji ustalili že po treh ponovitvah. Skupine je zamenjalo le manjše število enot. Podobno velja tudi za Novo mesto.

\section{PREDSTAVITEV IN INTERPRETACIJA REZULTATOV}

Osnovni namen analize je določiti, prostorsko omejiti in opisati homogena socialnomorfološka območja $v$ treh slovenskih mestih. $\mathrm{Z}$ metodo razvrščanja $\mathrm{v}$ skupine smo popisne okoliše razdelili $v$ homogene skupine, ki tako predstavljajo iskana mestna območja. Takšna delitev mest nam omogoča izdelavo tipologije mestnih območij, ki temelji na kompleksnem kriteriju, ki vključuje tako socialne značilnosti prebivalstva, kot morfološki zgradbo.

Naslednji korak je opis osnovnih značilnosti posameznih socialno-morfoloških območij. Ker se obe razvrstitvi, to je po metodi hierarhičnega razvrščanja v skupine in po metodi voditeljev bistveno ne razlikujeta (kar je razvidno tudi iz priloženih kart), bomo interpretirali obe razvrstivi (dobljeni po obeh omenjenih metodah) hkrati. Zaradi razlik med številom homogenih, bolj ali manj izrazitih skupin med tremi proučevanimi mesti pa je očitno, da je potrebno obravnavati vsako mesto ločeno. Kot zaključek bo kljub temu izdelan poskus skupne tipologije mestnih socialnomorfoloških območij.

\subsection{Celje:}

Iz tabele 1 , ki podaja srednje vrednosti spremenljivk za skupine, dobljene po metodi hierarhičnega razvrščanja $v$ skupine in končne voditelje skupin, je možno določiti osnovne značilnosti posameznih skupin, to se pravi socialno-morfoloških območij mesta.

Značilnosti prve skupine so: prevlada enodružinskih hiš (le ena četrtina stanovanj je v večstanovanjskih hišah), nadpovprečen delež stanovanj, zgrajenih med obema voj- 
nama in tudi pred letom 1918 ter izrazito malo stanovanj zgrajenih $\mathrm{v}$ zadnih dveh desetletjih $(16 \%)$, relativno slaba premoženjska raven prebivalstva (odmerjena dohodnina le 235.000 SIT proti 273.000 za celotno mesto), nadpovprečen delež industrijskih delavcev in podpovprečen delež zaposlenih $\mathrm{v}$ kvartarnih dejavnostih ter vodilnih delavcev, slaba izobrazbena struktura prebivalstva (izrazito nadpovprečen delež prebivalcev z osnovnošolsko izobrazbo ali brez izobrazbe in majhen delež prebivalcev $\mathrm{z}$ visoko ali višjo izobrazbo) in nadpovprečno staro prebivalstvo. Vrednosti ostalih spremenljivk so blizu povprečju za celo mesto. Iz karte 1 je razvidno, da gre za mestno obrobje, oziroma za primestna naselja, ki so bila šele nedavno $\mathrm{z}$ širjenjem mesta vključena $v$ urbano območje. Obsega obmestna naselja Babno, Šmarjeta, Trnovlje, Podgorje, Košnica in tudi del industrijskega predmestja Gaberje. $\mathrm{Za}$ to območje je torej značilna podpovprečna premoženjska raven in izobrazbena struktura, nadpovprečen delež industrijskih delavcev in starejših prebivalcev. Opazno je tudi, da $v$ zadnjem časovnem obdobju v mestnem obrobju ni bilo posebno intenzivne gradnje novih stanovanj.

Tabela 1: Srednje vrednosti in vrednosti voditeljev po posameznih spremenljivkah.

\section{Skupine}

srednje vrednosti (\%)

\begin{tabular}{lrrrrrrrrrr}
\hline spremenljivka & I & II & III & IV & V & I & II & III & IV & V \\
\hline preb. do 18 leta & 18,47 & 18,55 & 18,71 & 23,86 & 31,83 & $-0,45$ & $-0,52$ & $-0,38$ & 0,22 & 1,29 \\
prebivalstvo nad 65 let & 19,36 & 13,71 & 15,58 & 14,23 & 3,60 & 0,36 & 0,26 & 0,23 & 0,07 & $-0,91$ \\
preb. s kon. OŠ ali manj & 45,30 & 24,22 & 35,26 & 46,10 & 40,36 & 0,98 & $-0,95$ & $-0,16$ & 0,58 & 0,12 \\
višja ali visoka izobraz. & 6,89 & 17,70 & 12,23 & 5,37 & 9,79 & $-0,96$ & 0,96 & 0,06 & $-0,61$ & $-0,02$ \\
delež neslov. preb. & 19,20 & 15,21 & 19,18 & 20,77 & 13,88 & 0,08 & $-0,28$ & 0,28 & 0,46 & $-0,33$ \\
delež indust. delavcev & 40,41 & 27,30 & 31,25 & 37,83 & 33,89 & 0,96 & $-0,64$ & $-0,22$ & 0,28 & 0,01 \\
delež vodilni delavcev & 1,67 & 7,27 & 2,75 & 1,10 & 4,02 & $-0,46$ & 0,76 & $-0,28$ & $-0,55$ & 0,13 \\
delež zapos. v sek. sektor. & 42,50 & 39,05 & 37,72 & 36,07 & 39,70 & 0,48 & $-0,28$ & 0,08 & $-0,32$ & 0,05 \\
delež zapos. v terc. sektor. & 34,89 & 35,51 & 33,59 & 40,14 & 37,02 & $-0,12$ & 0,07 & $-0,24$ & 0,30 & 0,09 \\
deležz zapos. v kvart. sek. & 17,21 & 22,95 & 26,63 & 21,55 & 22,06 & $-0,44$ & 0,07 & 0,41 & $-0,04$ & 0,00 \\
dohod./ preb. v 000 SIT & 234 & 354 & 298 & 200 & 257 & $-0,74$ & 0,99 & 0,27 & $-1,14$ & $-0,12$ \\
delež nezaposlenih preb. & 5,62 & 6,10 & 7,84 & 17,88 & 5,98 & $-0,19$ & $-0,30$ & $-0,02$ & 1,18 & $-0,22$ \\
delež samskih gospodinj. & 25,19 & 16,12 & 27,72 & 33,50 & 18,42 & 0,06 & $-0,39$ & 0,24 & 0,93 & $-0,44$ \\
stan. površina na osebo & 24,67 & 27,97 & 23,29 & 24,98 & 19,80 & $-0,01$ & 0,80 & $-0,22$ & 0,14 & $-0,81$ \\
delež stan. v večstan. $h$. & 23,79 & 21,30 & 87,16 & 82,20 & 90,08 & $-0,92$ & $-0,82$ & 0,60 & 0,54 & 0,76 \\
d. stan. zgrajen do l. 1918 & 26,47 & 7,66 & 7,44 & 82,68 & 3,56 & $-0,45$ & $-0,52$ & $-0,39$ & 0,22 & 1,29 \\
d. stan. z. med 1919-45 & 23,58 & 10,50 & 3,08 & 6,03 & 2,11 & 0,87 & 0,27 & $-0,46$ & $-0,18$ & $-0,44$ \\
d. stan. z. med 1946-70 & 32,51 & 40,32 & 80,69 & 4,79 & 2,75 & $-0,27$ & 0,20 & 1,34 & $-0,84$ & $-0,93$ \\
del. stan. zgraj. po 1971 & 16,77 & 40,51 & 8,48 & 6,25 & 91,36 & $-0,40$ & $-0,01$ & $-0,68$ & $-0,74$ & 1,57 \\
\hline
\end{tabular}

Druga skupina ima naslednje značilnosti: prevlada enodružinskih hiš, zgrajenih v povojnem obdobju ( $80 \%)$, manjši del (10\%) tudi med vojnama, nadpovprečna 
stanovanjska površina na osebo, majhen delež samskih gospodinjstev, zelo visoka premoženjska raven prebivalstva (354.000 SIT odmerjene dohodnine na prebivalca), dobra izobrazbena struktura, majhen delež industrijskih in visok delež vodilnih delavcev in nadpovprečno staro prebivalstvo. Podpovprečne vrednosti izkazuje tudi delež neslovenskega prebivalstva, delež samskih gospodinjstev in delež nezaposlenih. Iz karte je razvidno, da gre za novejše soseske enodružinskih hiš Ostrožno, Lava, Nova vas, Zgornja Hudinja, Medlog in Polule, ter za dve "vilski" soseski, zgrajeni med vojnama: Otok in Aljažev hrib. To so torej deli mesta z "najvišjo" socialno strukturo, sovpadajo po z območji enodružinskih hiš.

Karta 1: Celje — razvrstitev stanovanjskih območij v skupine.

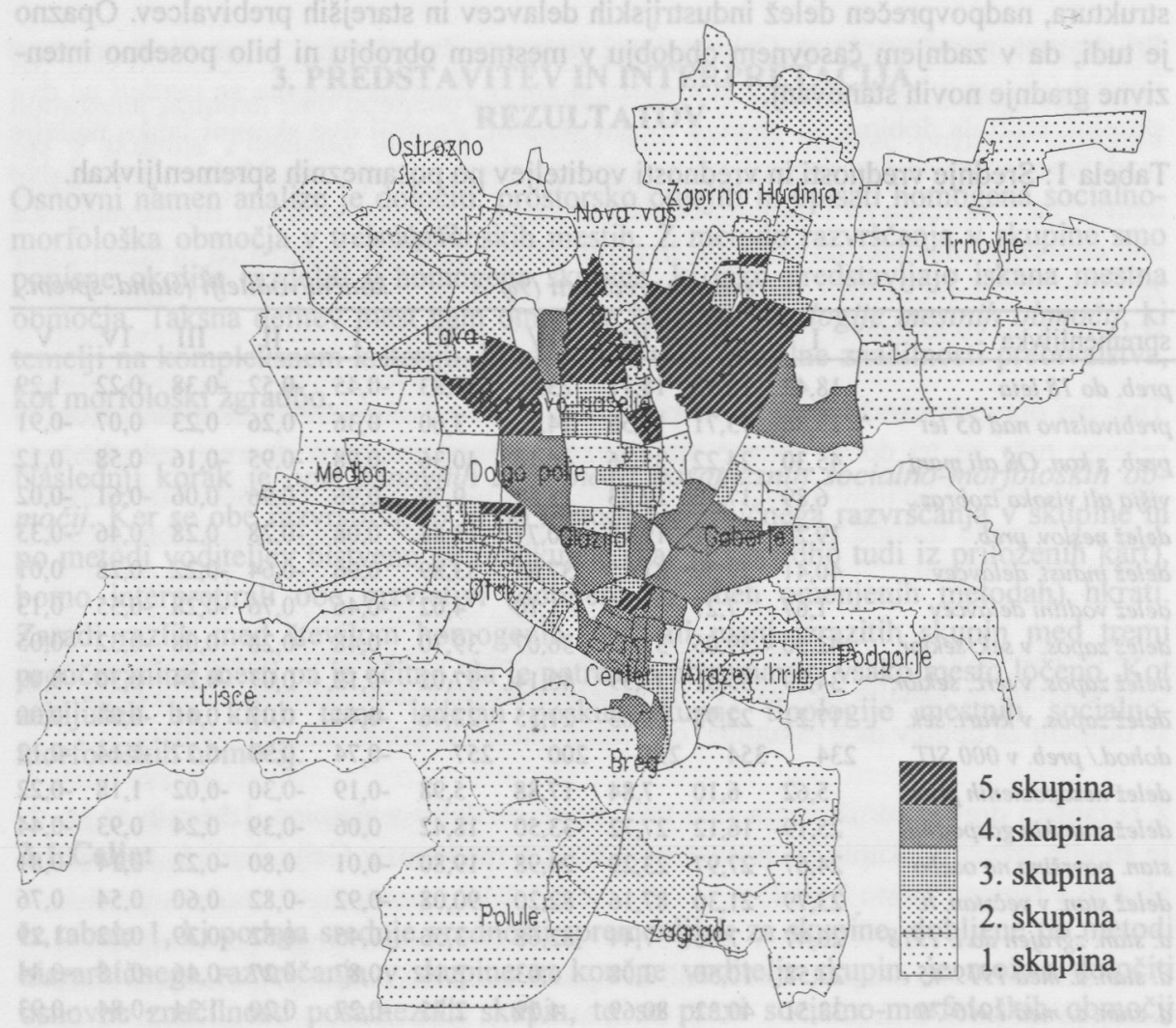


V tretjo skupino so uvrščene blokovske soseske Otok, Dečkovo naselje ter del četrti Dolgo polje, Zgornja Hudinja in Glazija (tisti deli teh četrti, kjer prevladujejo večstanovanjske hiše). To so pretežno med leti 1946 in 1971 zgrajene blokovske soseske. Za njih je značilna socialna struktura prebivalstva, ki ne odstopa bistveno od povprečja za celotno mesto. Nekoliko nadpovprečna je premoženjska struktura ter delež neslovenskega prebivalstva, nekoliko podpovprečna pa izobrazbena struktura.

Od ostalih skupin po svojih značilnostih zelo izrazito odstopa četrta skupina. V celoti se ujema z mestnim središčem, obsega pa tudi starejše industrijsko predmestje Gaberje. Velika večina stanovanj je bila zgrajenih pred letom 1918. Prevladujejo večstanovanjske hiše. Ti dve starejši območji mesta imata izrazito "slabo" socialno strukturo: prevladuje prebivalstvo $\mathrm{z}$ nizkimi dohodki (odmerjena dohodnina na prebivalca le 200.000 SIT!), slabo izobrazbeno strukturo, izredno visok je delež nezaposlenih $(18 \%)$. Značilen je tudi izrazito nadpovprečen delež neslovenskega prebivalstva $(21 \%)$ in delež samskih gospodinjstev (33\%). Zanimivo je, da je nadpovprečen tudi delež prebivalcev pod 18 letom starosti in s tem delež mladih družin. Očitno je torej, da se starejša območja Celja (mestno središče in Gaberje) ujemajo z območji "slabe" socialne strukture.

Tabela 2: Celje, osnovne značilnosti stanovanjskih območij.

\begin{tabular}{|l|l|l|}
\hline & morfološke značilnosti & socialna struktura prebivalstva \\
\hline 1. skupina & $\begin{array}{l}\text { obmestna naselja enodružin- } \\
\text { skih hiš }\end{array}$ & $\begin{array}{l}\text { nizki dohodki prebivalcev, visok delež } \\
\text { industrijskih delavcev, slaba } \\
\text { izobrazbena struktura }\end{array}$ \\
\hline 2. skupina & soseske enodružinskih hiš & $\begin{array}{l}\text { visoki dohodki, visok delež vodilnih } \\
\text { delavcev, dobra izobrazbena struktura }\end{array}$ \\
\hline 3. skupina & $\begin{array}{l}\text { blokovske soseske, zgrajene } \\
\text { med leti } 1946 \text { in 1971 }\end{array}$ & $\begin{array}{l}\text { socialna struktura prebivalstva ne } \\
\text { odstopa bistveno od povprečja za celo } \\
\text { mesto }\end{array}$ \\
\hline 4. skupina & starejši deli mesta & $\begin{array}{l}\text { zelo nizki dohodki prebivalcev, slaba } \\
\text { izobrazbena struktura, zelo visok delež } \\
\text { nezaposlenih, malo samskih } \\
\text { gospodinjstev }\end{array}$ \\
\hline 5. skupina & novejše blokovske soseske & $\begin{array}{l}\text { prevlada mladih družin, majhna } \\
\text { stanovanjska površina na osebo }\end{array}$ \\
\hline
\end{tabular}

V peto skupino so se uvrstile najnovejše blokovske soseske, zgrajene po letu 1971. To so deli četrti Lava, Nova vas in Zgornja Hudinja (tisti deli, kjer prevladujejo večstanovanjske hiše). Torej so vse tri soseske, zgrajene po letu 1971, razdeljene na 
dva dela: "blokovski" in "enodružinski" del. Osnovna značilnost te skupine je prevlada mladih družin (delež prebivalcev do 18 leta starosti je kar $32 \%$ ). Značilen je tudi majhen delež neslovenskega prebivalstva, samskih gospodinjstev ter izrazito podpovprečna stanovanjska površina na osebo (kar je glede na prevlado mladih družin razumljivo).

V vsaki skupini lahko torej izdvojimo nekaj spremenljivk, ki izrazito odstopajo od povprečja (visoke vrednosti končnih voditeljev!) in s tem označujejo posamezne dele mesta. Osnovne značilnosti posameznih skupin so razvidne iz naslednje tabele.

\subsection{Koper:}

Tabela 3: Srednje vrednosti in vrednosti voditeljev po posameznih spremenljivkah.

\section{Skupine}

srednje vrednosti (\%) Končni voditelji (stand. spr.)

\begin{tabular}{|c|c|c|c|c|c|c|c|c|}
\hline spremenljivka & I & II & III & IV & I & II & III & IV \\
\hline prebivalstvo do 18 let & 4 & 22,96 & 2 & 24,86 & 0,09 & 0,09 & $-0,71$ & 0,36 \\
\hline prebivalstvo nad 65 let & 7 & 9,24 & 11 & 6,73 & 0,60 & $-0,06$ & 0,42 & $-0,68$ \\
\hline preb. s končano OŠ ali manj & 7 & 46,8 & 2 & 3 & 0,22 & 1,0 & $-1,16$ & $-0,05$ \\
\hline preb. z višjo ali visoka izobr. & 1 & 7,89 & 22,87 & 13,23 & $-0,29$ & $-0,80$ & 1,08 & 0,05 \\
\hline delež neslov. prebivalstva & 24,10 & 24,32 & 27,97 & 20,79 & 0,05 & 0,03 & 0,29 & $-0,25$ \\
\hline delež industrijskih delavcev & 33,65 & 37,09 & 16,82 & 29,76 & 0,37 & 0,52 & $-1,00$ & 0,07 \\
\hline delež vodilnih delavcev & 1,58 & 2,22 & 4,84 & 4,34 & $-0,60$ & $-0,33$ & 0,48 & 0,32 \\
\hline delež zapos. v sekundar. sek. & 20,93 & 30,21 & 19,24 & 26,26 & $-0,37$ & 0,53 & $-0,48$ & 0,23 \\
\hline delež zapos. v terciar. sek. & 49,43 & 38,28 & 46,16 & 4. & 0,34 & $-0,52$ & 0,23 & $-0,04$ \\
\hline delež zapos. v kvartar. sek. & 27,04 & 27,72 & 30,27 & 26,72 & $-0,06$ & 0,00 & 0,24 & $-0,10$ \\
\hline dohodnina na preb. $v 000$ SIT & 283 & 280 & 476 & 315 & $-0,37$ & $-0,47$ & 1,02 & $-0,11$ \\
\hline delež nezapos. prebivalcev & 15,70 & 12,08 & 8,40 & 11,77 & 0,53 & $-0,07$ & $-0,56$ & 0,05 \\
\hline delež samskih gospodinjstev & 22,66 & 18,40 & 22,31 & 14,06 & 0,34 & 0,08 & 0,28 & $-0,48$ \\
\hline stanov. površina na osebo $\mathrm{v} \mathrm{m}^{2}$ & 25,31 & 21,05 & 29,43 & 22,21 & 0,10 & $-0,45$ & 0,83 & $-0,33$ \\
\hline delež stan. v več-stan. hišah & 52,31 & 56,90 & 42,74 & 81,02 & $-0,26$ & $-0,05$ & $-0,41$ & 0,51 \\
\hline delež stan. zgraj. do leta 1918 & 72,42 & 17,39 & 2,42 & 2,25 & 1,68 & $-0,34$ & $-0,57$ & $-0,57$ \\
\hline delež stan. zgraj. med l. 1919-45 & 1,77 & 1,67 & 0,19 & 0,48 & 0,18 & 0,25 & $-0,24$ & $-0,13$ \\
\hline delež stan, zgra. med l. 1946-71 & 10,88 & 57,45 & 76,11 & 3,64 & $-0,71$ & 0,73 & 1,07 & $-0,73$ \\
\hline delež stan. zgrajenih po l. 1971 & 14,43 & 23,28 & 21,02 & 93,48 & $-0,77$ & $-0,45$ & $-0,53$ & 1,22 \\
\hline
\end{tabular}

Prva skupina obsega večino starega mestnega središča, poleg tega pa tudi manjši del soseske Olmo. Velika večina stanovanj je bila zgrajenih pred letom 1918, četrtina pa 
tudi po letu 1946. Delež stanovanj $\mathrm{v}$ večstanovanjskih hišah je nekoliko podpovprečen. Za socialno strukturo prebivalstva je značilna relativno slaba premoženjska raven in izobrazbena struktura, visok delež nezaposlenih in industrijskih delavcev ter nizek delež vodilnih delavcev. Prav tako je značilen visok delež prebivalstva nad 65 letom starosti in delež samskih gospodinjstev.

Karta 2: Koper - razvrstitev stanovanjskih območij v skupine.

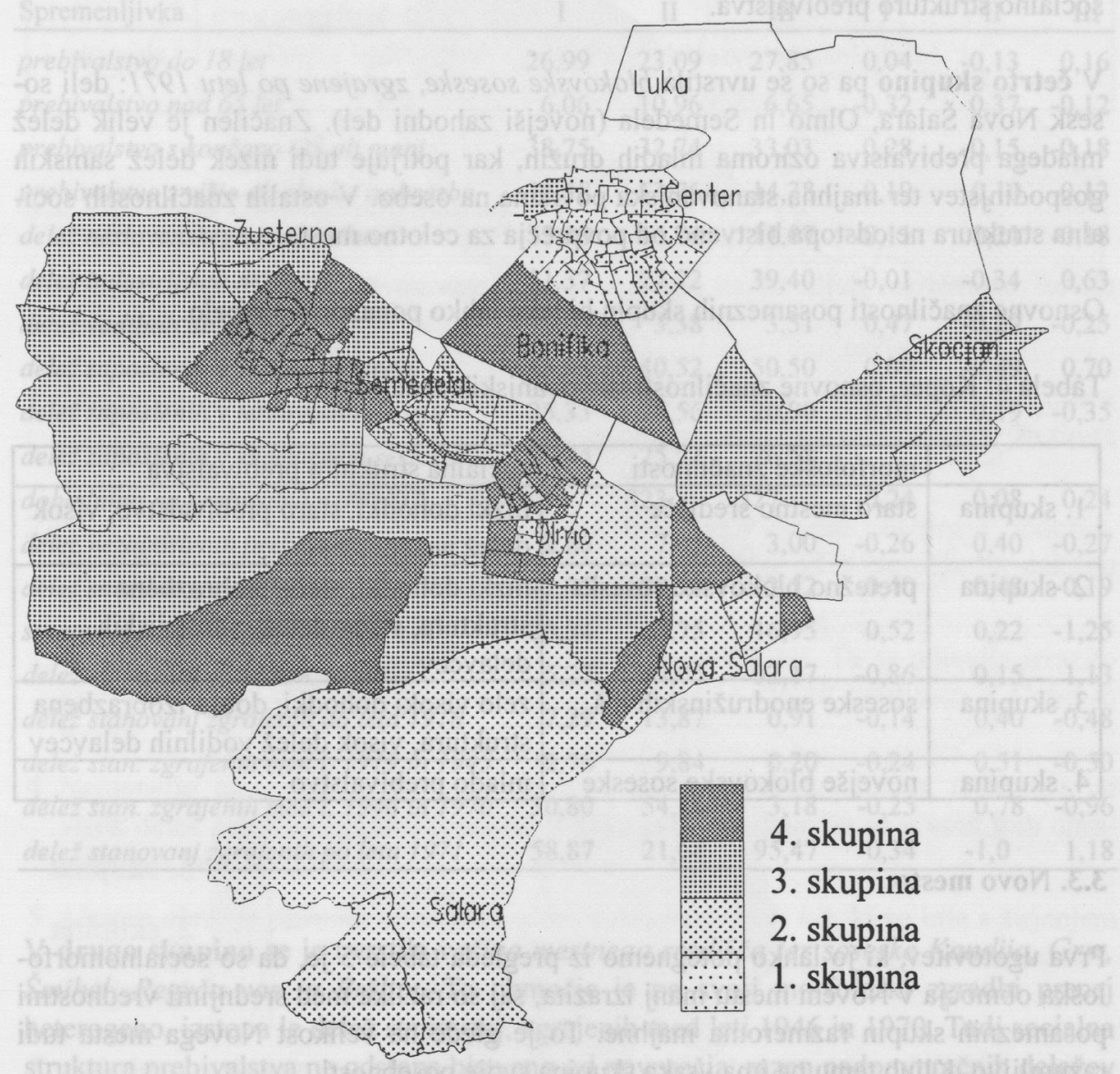

V drugi skupini so blokovske soseske Nova Šalara, Olmo in obmestno naselje Šalara. Velik del stanovanj je bil zgrajen med leti 1946 in 1970, del tudi po letu 1971 (23\%) in pred letom 1918 (17\% - Šalara). Delež stanovanj v blokih je relativno visok $(56 \%)$. Značilna je slaba premoženjska raven prebivalstva, poleg tega pa tudi slaba izobrazbena struktura in visok delež industrijskih delavcev. 
Osnovna značilnost tretje skupine so zelo visoki dohodki prebivalcev, ugodna izobrazbena struktura, nizek delež industrijskih in visok delež vodilnih delavcev. Značilen je tudi nizek delež nezaposlenih in velika stanovanjska površina na osebo. Gre torej za izrazito nadpovprečno "visoko" socialno strukturo prebivalstva. Ta skupina obsega osrednji del naselja Semedela in del Žusterne, to se pravi območje, ki je bilo večinoma zgrajeno med leti 1946 in 1970. Prevladujejo enodružinske hiše, toda tudi delež večstanovanjskih hiš ni zanemarljiv. Gre torej za območje z najboljšo socialno strukturo prebivalstva.

V četrto skupino pa so se uvrstila blokovske soseske, zgrajene po letu 1971: deli sosesk Nova Šalara, Olmo in Semedela (novejši zahodni del). Značilen je velik delež mladega prebivalstva oziroma mladih družin, kar potrjuje tudi nizek delež samskih gospodinjstev ter majhna stanovanjska površina na osebo. V ostalih značilnostih socialna struktura ne odstopa bistveno od povprečja za celotno mesto.

Osnovne značilnosti posameznih skupin bi tako lahko ponazorili s tabelo.

Tabela 4: Koper, osnovne značilnosti stanovanjskih značilnosti.

\begin{tabular}{|l|l|l|}
\hline morfološke značilnosti & socialna struktura prebivalstva \\
\hline 1. skupina & staro mestno središče & $\begin{array}{l}\text { nizki dohodki, staro prebivalstvo, visok } \\
\text { delež nezaposlenih }\end{array}$ \\
\hline 2. skupina & pretežno blokovske soseske & $\begin{array}{l}\text { nizki dohodki, slaba izobrazbena } \\
\text { struktura, visok delež industrijskih } \\
\text { delavcev }\end{array}$ \\
\hline 3. skupina & soseske enodružinskih hiš & $\begin{array}{l}\text { zelo visoki dohodki, dobra izobrazbena } \\
\text { struktura, visok delež vodilnih delavcev }\end{array}$ \\
\hline 4. skupina & novejše blokovske soseske & mlado prebivalstvo \\
\hline
\end{tabular}

\subsection{Novo mesto:}

Prva ugotovitev, ki jo lahko potegnemo iz pregleda tabele 5 je, da so socialnomorfološka območja v Novem mestu manj izrazita, saj so razlike med srednjimi vrednostmi posameznih skupin razmeroma majhne. To je glede na velikost Novega mesta tudi razumljivo. Kljub temu pa ima vsaka skupina svoje posebnosti.

Prva skupina obsega predvsem mestno obrobje, ki je v primeru Novega mesta še deloma ohranilo polruralni značaj (delež zaposlenih $v$ primarnem sektorju presega $7 \%$ ): Žabja vas, Gotna vas, Jedinščica, Brod, Kamence in Bučna vas. V celoti prevladujejo enodružinske hiše, zgrajene pretežno po letu 1971, deloma tudi med letoma 1946 in 1970 . Značilna je nekoliko podpovprečna premoženjska struktura prebival- 
stva, relativno slaba izobrazbena struktura, majhen delež samskih gospodinjstev in visok delež vodilnih delavcev.

Tabela 5: Srednje vrednosti in vrednosti voditeljev po posameznih spremenljivkah.

\section{Skupina}

srednje vrednosti (\%) končni voditelj(stand. spr.)

\begin{tabular}{lrrrrrr}
\hline Spremenljivka & I & II & III & I & II & III \\
\hline prebivalstvo do 18 let & 26,99 & 23,09 & 27,85 & 0,04 & $-0,13$ & 0,16 \\
prebivalstvo nad 65 let & 6,06 & 10,96 & 6,65 & $-0,32$ & 0,37 & $-0,12$ \\
prebivalstvo s končano OŠ ali manj & 38,75 & 32,74 & 33,03 & 0,28 & $-0,15$ & $-0,18$ \\
prebivalstvo z višjo ali visoko izobrazbo & 11,18 & 13,76 & 14,38 & $-0,19$ & 0,10 & 0,13 \\
delež neslovenskega prebivalstva & 12,58 & 16,74 & 11,07 & $-0,11$ & 0,21 & $-0,18$ \\
delež industrijskih delavcev & 31,37 & 27,72 & 39,40 & $-0,01$ & $-0,34$ & 0,63 \\
delež vodilnih delavcev & 6,07 & 3,38 & 3,51 & 0,47 & $-0,29$ & $-0,25$ \\
delež zaposlenih v sekund. sektorju & 43,98 & 40,52 & 50,50 & 0,09 & $-0,49$ & 0,70 \\
delež zaposlenih v tercirnem sektorju & 25,33 & 25,56 & 20,90 & 0,01 & 0,19 & $-0,35$ \\
delež zaposlenih v kvartarnem sektorju & 23,34 & 25,22 & 26,58 & & & \\
dohodnina na prebivalca v00 SIT & 295 & 323 & 327 & $-0,24$ & 0,08 & 0,24 \\
delež nezaposlenih prebivalcev & 2,86 & 7,01 & 3,00 & $-0,26$ & 0,40 & $-0,27$ \\
delež samskih gospodinjstev & 12,35 & 22,57 & 13,12 & $-0,40$ & 0,48 & $-0,19$ \\
stanovanjska površina na osebo v m ${ }^{2}$ & 25,34 & 23,75 & 16,95 & 0,52 & 0,22 & $-1,25$ \\
delež stanovanj v večstan. hišah & 5,27 & 44,05 & 92,17 & $-0,86$ & 0,15 & 1,13 \\
delež stanovanj zgrajenih do leta 1918 & 7,29 & 13,87 & 0,91 & $-0,14$ & 0,40 & $-0,48$ \\
delež stan. zgrajenih med l. 1919 in 1945 & 2,76 & 9,84 & 0,20 & $-0,24$ & 0,51 & $-0,50$ \\
delež stan. zgrajenih med l. 1946 in 1970 & 30,80 & 54,18 & 3,18 & $-0,25$ & 0,78 & $-0,96$ \\
delež stanovanj zgrajenih po letu 1971 & 58,87 & 21,64 & 95,47 & 0,34 & $-1,0$ & 1,18 \\
\hline & & & & & &
\end{tabular}

V drugo skupino se je uvrstila večina mestnega središča ter soseske Kandija, Grm, Šmihel, Regrča vas in Bršljin. To območje je po svoji morfološki zgradbi precej heterogeno, izstopa le delež stanovanj, zgrajenih med leti 1946 in 1970 . Tudi socialna struktura prebivalstva ne odstopa bistveno od povprečja, razen nadpovprečnih deležev samskih gospodinjstev, deleža nezaposlenih in deleža starejšega prebivalstva.

Tretja skupina se ujema z najnovejšimi blokovskimi soseskami (zgrajenimi po letu 1971). Odstopa predvsem visok delež industrijskih delavcev, majhna stanovanjska površina na osebo ter nekoliko nadpovprečen delež mlajšega prebivalstva. Tabela 6 prikazuje osnovne značilnosti posameznih skupin. 
Karta 3: Novo mesto - razvrstitev stanovanjskih območij v skupine

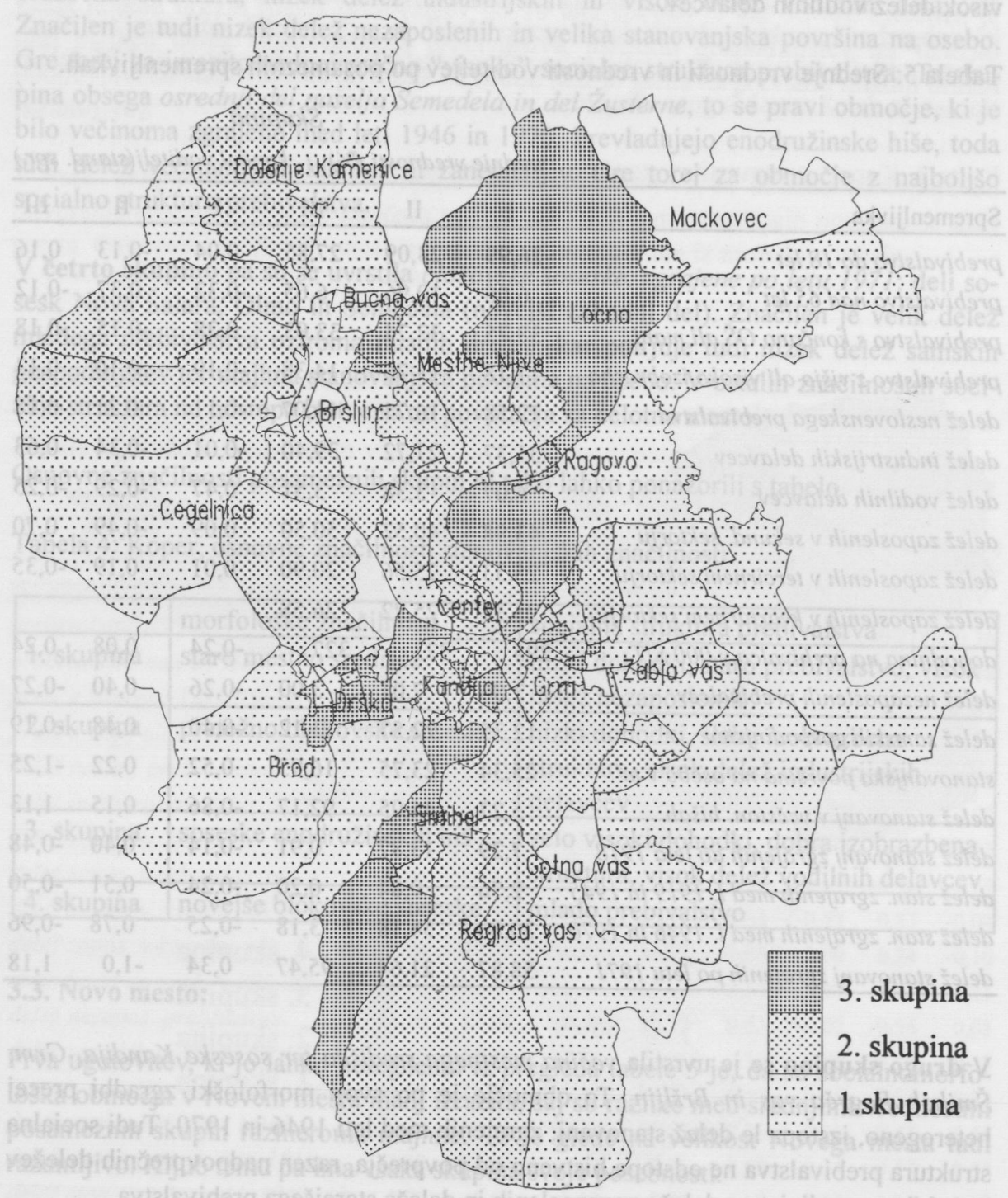

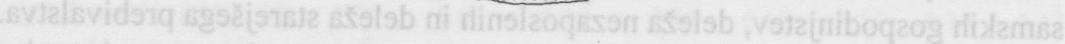

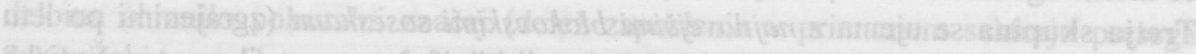

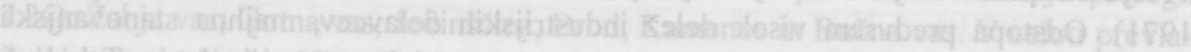

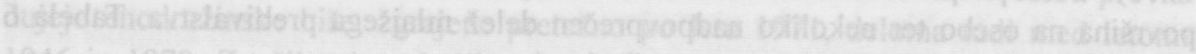


Tabela 6: Novo mesto, osnovneznačilnosti stanovanjskih območij.

\begin{tabular}{|l|l|l|}
\hline & morfološke značilnosti & socialna struktura prebivalstva \\
\hline 1. skupina & $\begin{array}{l}\text { obmestna naselja } \\
\text { enodružinskih hiš }\end{array}$ & $\begin{array}{l}\text { relativno slaba premoženjska in izobrazbena } \\
\text { struktura }\end{array}$ \\
\hline 2. skupina & $\begin{array}{l}\text { mestno središče in } \\
\text { predmestne } \\
\text { stanovanjske četrti }\end{array}$ & $\begin{array}{l}\text { nadpovprečen delež nezaposlenih in delež } \\
\text { starega prebivalstva }\end{array}$ \\
\hline 3. skupina & $\begin{array}{l}\text { najnovejše blokovske } \\
\text { soseske }\end{array}$ & $\begin{array}{l}\text { mlajše prebivalstvo, visok delež } \\
\text { industrijskih delavcev }\end{array}$ \\
\hline
\end{tabular}

\subsection{Tipologija stanovanskih območij}

Primerjava med tremi obravnavanimi mesti pokaže, da so kljub različnemu številu skupin opazne nekatere podobnosti.

1. Mestno središče in starejša predmestja: gre za najstarejši del mesta, večinoma zgrajen pred letom 1918. Značilna je slaba socialna struktura prebivalstva. Ta tip je izrazit v Celju in Kopru, precej manj pa v Novem mestu.

2. Stanovanjske, pretežno blokovske soseske, zgrajene v prvem povojnem obdobju. Značilna je socialna struktura, ki ne odstopa bistveno od povprečja za celotno mesto. Ta tip je opaziti v Celju in Kopru.

3. Novejše stanovanjske soseske s prevlado enodružinskih hiš. Tu se pojavlja izrazito visoka socialna struktura prebivalstva. Tudi ta tip je izrazit predvsem v Celju in Kopru.

4. Najnovejše blokovske soseske, zgrajene v zadnjih dveh desetletjih. Označuje jih visok delež mladega prebivalstva (oz. mladih družin). Pojavlja se v vseh treh obravnavanih mestih.

5. Mestno obrobje oziroma obmestna naselja enodružinskih hiš, ki so bila s širjenjem mesta vključena $v$ urbano območje. Značilna je relativno slaba socialna struktura. Ta tip je prisoten v Celju in Novem mestu.

$\mathrm{Z}$ metodo razvrščanja $\mathrm{v}$ skupine smo torej razdelili stanovanjsko območje mesta $\mathrm{v}$ značilne in relativno homogene tipe. Omenjena metoda omogoča kompleksno tipizacijo, ki temelji na celi vrsti spremenljivk. Dobljeni rezultati so potrdili naše začetne domneve o povezanosti morfološke zgradbe mesta in socialne strukture prebivalstva. Očitna je tudi prostorska socialna segregacija prebivalstva, ki pa ni posebno izrazita. $\mathrm{Z}$ nadaljnim povečevanjem socialnih razlik med različnimi skupinami prebivalstva lahko pričakujemo tudi poglabljanje tega procesa. 


\section{LITERATURA}

Bagatelj, V. 1979: Razvrščanje v skupine - osnovni pojmi, Seminar za numerično in računalniško matematiko, 159, DMFA SR. Ljubljana.

Berry, B.L.; Horton, F.E. 1970: Geographic Perspectives on Urban Systems, Prentice Hall, Engelwoods Clifs. New Jersy.

Drozg, V. 1990: Členitev mestnega območja Izole. 15. zborovanje slovenskih geografov, str. 169-176. Portorož.

Ferligoj, A. 1989: Razvrščanje v skupine. Metodološki zvezki 4. Ljubljana.

Lichtenberger, E., 1986, Stadtgeographie. Teuber, Stuttgart.

Pak, M. 1974: Geografski elementi socialnega razlikovanja v mestnem prostoru. Geographica Slovenica 3. Ljubljana.

Seger, M. 1988: Die Stadtstruktur von Villach - Eine statistische Analise nach Zahlbezirken, Stadt und Umwelt - Arbeiten zum Grünraumsituation in Villach. Villach.

\section{TYPOLOGY OF RESIDENTIAL DISTRICTS THROUGH THE APPLICATION OF CLUSTER ANALYSIS IN THE CASES OF CELJE, KOPER, AND NOVO MESTO}

\section{Summary}

The aim of the study is to form a typology of residential districts in the cases of three medium-sized Slovenian towns: Celje, Koper and Novo mesto. In these three towns residential districts have been identified which strongly resemble one another in their social and morphological structures. In doing this, spatial distribution of the so defined residential districts in towns has also been taken into account. City districts without residential function have intentionally been excluded from the analysis, and named as the non-residential districts. These are, above all, the zones of manufacturing industry and warehouses, transport terminals, recreational areas and larger complexes of public houses.

Homogeneous residential districts were specified on the basis of the data on the social structure of population and the morphological structure of urban space. In fact, it is the matter of forming a complex typology of town districts.

For the identification of typical homogeneous residential districts cluster analysis was applied. In the first part of the study, cluster analysis is presented in detail as a method which renders possible the ranking of units or 'objects', defined by variables, into several groups. They are defined in such a way that the units within an individual group are as much alike as possible, while the groups differ one from the other as much as possible. For the purpose of the study, hierarchical cluster analysis and k-means ana- 